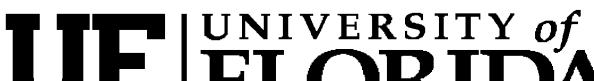 FLORIDA \\ IFAS Extension
}

FOR187

\section{Expanding Florida's Farming Business to Incorporate Tourism 1}

Wendy Francesconi and Taylor Stein ${ }^{2}$

\section{Introduction}

In 2005, more tourists visited Florida than ever before, and the state was ranked the number one tourism destination in the world (Visit Florida, 2006). Receiving more than 80 million tourists per year, Florida provides a wealth of recreation and relaxation opportunities. Although tourism is a dominant industry in Florida, producing more than $\$ 57$ billion/year if indirect effects are taken into account (State of Florida, 2006), the state would not be what it is today without agriculture leading the way.

With citrus groves, sugar cane, ornamentals, timber and other agricultural products, Florida is one of the nation's top ten most productive agricultural states. However, small and medium-size farms in Florida are undergoing the same economical crisis as other farms in the country. Competition with industrial agricultural corporations, high business expenses and low commodity prices are challenging the feasibility of small agricultural businesses. These reasons, along with Florida's massive population growth are contributing to the conversion of small and medium-sized farms into urban development projects.
Given Florida's proven success with tourism, favorable climate, abundant wildlife, and the diversity of farming products, Florida farms make great candidates for agritourism operations. It may be time to bring Florida's two economic engines (tourism and agriculture) together. In order to increase the value of farms and to expand the array of recreation experiences offered in Florida, many agricultural and tourism professionals are touting agritourism as one alternative for small and medium farming operations to generate additional income. However, agritourism implies a different business management scheme compared to agriculture, and farmers considering agritourism should be prepared to adapt their product-based businesses to join the leisure-based industry.

\section{Current Farming Situation in Florida}

Of Florida's 35,000,000 acres, 10,000,000 acres are used for farming. This includes about 40,000 farm operations that together produced cash receipts for around $\$ 6.2$ billion in 2002 (NASS, 2006). However, the farming business and the numbers of farms are declining throughout the state. In the 1990s, the agricultural economy increased only $5 \%$ compared to

1. This document is FOR187, one of a series of the School of Forest Resources and Conservation Department, Florida Cooperative Extension Service, Institute of Food and Agricultural Sciences, University of Florida. Original publication date June 2008. Visit the EDIS Web Site at http://edis.ifas.ufl.edu.

2. Wendy Francesconi, PhD Candidate, School of Forest Resources and Conservation, University of Florida, Gainesville, FL 32611. Taylor V. Stein, associate professor, School of Forest Resources and Conservation, University of Florida, Gainesville, FL 32611.

The Institute of Food and Agricultural Sciences (IFAS) is an Equal Opportunity Institution authorized to provide research, educational information and other services only to individuals and institutions that function with non-discrimination with respect to race, creed, color, religion, age, disability, sex, sexual orientation, marital status, national origin, political opinions or affiliations. U.S. Department of Agriculture, Cooperative Extension Service, University of Florida, IFAS, Florida A. \& M. University Cooperative Extension Program, and Boards of County Commissioners Cooperating. Larry Arrington, Dean 
$25 \%$ and $50 \%$ in previous decades (NASS, 2006). In addition, property taxes continue to increase throughout Florida, making it more difficult for farmers to break even (Evans and Hodges, 2006). As a result, 10,000 acres of land are lost each year to urban development (Kolankiewicz and Beck, 2006).

\section{Why Should Florida Farmers Consider Agritourism?}

Farm tourism is now considered a potential new cash crop for farmers throughout the United States. According to the National Survey on Recreation and the Environment 2000-01 (Cordell, 2004), every year 63 million Americans travel an average of 80 miles to visit agritourism farms and spend between $\$ 5$ to $\$ 50$ per person in farm recreational activities. McKenzie and Wysocki (2002) in their UF/IFAS publication on Agritainment discussed a case study that showed New York farm tours hosted an average of 1500 visitors per year per farm. However, these estimations vary depending on the age and gender of the farm visitors (for instance, men tend to spend more than women, and younger people tend to spend less than older people). Farm visitor spending is also positively correlated with the overall cost of the trip (people tend to spend more money on more expensive trips).

In addition to the financial returns, agritourism can benefit the environment and wildlife (Giuliano and Thomas, 2005). Some types of agritourism activities that involve wildlife are: bird watching, wildlife viewing, wildlife photography, and fishing. Hunting can also be used as a compatible enterprise that can complement agritourism activities.

Fee-hunting or hunting preserves for small or large game animals can be a lucrative tourism activity. Hunting fees on private lands that include lodging and meals could vary from a few hundred dollars to thousands of dollars (Brady Ranch, 2006). In fact, by managing their property for wildlife habitat, farmers may receive a secondary economic incentive from the federal government or conservation groups through programs like the Conservation Reserve Program or the purchase of conservation easements (NRCS, 2002).
Finally, agritourism can provide a diversity of social benefits to farmers and their communities. For example, agritourism is a valuable opportunity to educate the public about agriculture. In particular, local schools will often take advantage of local agritourism operations to provide students with a rare opportunity to see and experience agricultural operations and understand the source of their food. Also, farmers involved in agritourism have a direct market to customers and can promote local markets, which would decrease the environmental impact of food production (Evans and Hodges, 2006).

\section{Incorporating Agritourism within Florida Farms}

An agritourism operation, like any other business, requires planning. Since tourism is usually a supplement to existing agricultural operations, it is recommended to start small and build upon success. Regardless of the planned size, there are a few considerations to keep in mind. We suggest eight steps to help in this planning process:

\begin{tabular}{|l|}
\hline Planning for Agritourism \\
\hline 1. Identify vision and goals. \\
2. Understand surrounding tourism \\
opportunities \\
3. Create a business plan \\
4. Define and identify a market \\
5. Understand legal issues and purchase \\
liability insurance \\
6. Develop a strategy to manage visitors \\
7. Use Limits of Acceptable Change to \\
decrease negative impacts \\
8. Evaluate and monitor agritourism's costs \\
and benefits
\end{tabular}

These steps are described as follow:

1. Identify vision and goals. The first step before you work out the specific details of operating your business is to clarify why you want to start an agritourism operation and what benefits you hope to obtain. For example, if your goal is to add value to conservation lands, you can choose from a multitude of tourism opportunities that might produce extra revenue. These could include hunting leases, high value tours for small groups, or open and paid access to many visitors. The identification of your vision and goals will 
help determine the specific agritourism strategies you'll use.

\section{Understand surrounding tourism opportunities.}

Given that Florida is already a tourist destination, it is advantageous to identify tourism centers and attractions nearby. These could include traditional tourism attractions like beaches and amusement parks, nature-based recreation areas like state and national parks, or even other agritourism destinations. These other tourism destinations have the potential to compete with your new business unless you can foster a collaborative relationship with them in which all businesses help to expand the tourism opportunities offered in the area to everyone's benefit. Collaborate with neighboring tourism operations to tap into an existing market and learn from these established tourism businesses.

3. Create a business plan. A business plan should contain all the information regarding the development and execution of the agritourism activities (George and Rilla, 2005). This plan should comprise all the business components such as: a mission statement, goals, objectives, administrative and financial needs and strategies. The elaboration of the business plan will require an assessment of the farm's resources (e.g., land, water, infrastructure, and people), identification of the most appropriate recreation opportunities, and an assessment of the current market situation and competitive environment. To give farmers a better idea on moving forward with a business plan, the Southern Maryland Resources and Conservation Board and the USDA Natural Resources and Conservation Service (2004) published an on-line practical guide for farmers to begin the first steps towards agritourism and alternative income-producing opportunities.

\section{Define and identify a market. Farmers need to} understand the tourism market and identify the most efficient ways to target potential customers. In addition, farmers also need to distinguish unique features of their farming business that will help them attract those customers, as well as build strong community relations. For more information on how to market an agritourism business, please refer to George and Rilla's
(2005), Agritourism and Nature Tourism in California, or to the USDA/NRCS guide discussed above, or visit the UF/IFAS Small Farms Focus Team at http://smallfarm.ifas.ufl.edu/.

\section{Understand legal issues and purchase liability}

insurance. A major cost of inviting visitors onto a farm is liability insurance. Although lawsuits are rare (especially if the host behaves responsibly), anytime a landowner allows paid visitors onto his or her property, liability insurance must be acquired to protect that landowner from potentially high court costs. Since agritourism liability is still new to many insurance companies, landowners should check with their existing insurance company or the Florida Farm Bureau to learn the specifics in obtaining this type of insurance. Also, local tourism offices (e.g., county convention and visitor bureaus, chambers of commerce, and others) can offer advice on the legal issues associated with tourism and tips on purchasing liability insurance.

\section{Develop a strategy to manage visitors.}

Depending on the farm scale and tourism intensity, an agritourism operator will need to develop a management plan that will guide the management and planning of the tourism resources and visitors as they travel throughout the farm. The U.S. Forest Service has long worked to identify management frameworks to help managers work with the recreation setting and visitors. The Recreation Opportunity Spectrum is one strategy to help spatially organize tourism opportunities in an area (Clark and Stankey, 1979) and is particularly important in areas managed for multiple uses. The Recreation Opportunity Spectrum serves mainly as a zoning framework that can help farmers inventory potential agritourism opportunities and adopt specific management approaches for each zone.

7. Use Limits of Acceptable Change (Stankey et al., 1985) to decrease negative impacts. Limits of Acceptable Change is a useful framework developed to assist in the management of natural areas affected by human visitors the. It is based 
on the premise that any time visitors are allowed into natural areas (including farms), they will impact the area. Therefore, agritourism managers must answer the questions: how much impact is acceptable and what management opportunities are available to ensure these impacts stay within acceptable limits? A recreation management handbook produced at the University of Minnesota http://www.cnr.umn.edu/CPSP/Research/ revtactics_handbook.PDF. (Anderson, Lime, and Wang, 1998) can assist managers in identifying appropriate management strategies to ensure impacts stay within acceptable limits.

\section{Evaluate and monitor agritourism's costs and} benefits. Sustaining the quality of your operation can be a difficult job in agritourism operations. It requires the manager to systematically record impacts to people (e.g., visitor experience), finances (e.g., operational costs and revenues), and the environment (e.g., impacts to natural resources). With effective monitoring, you can avoid surprises and alter your management to ensure you are obtaining maximum and sustainable benefits.

\section{Conclusions}

The state of Florida exhibits many characteristics desirable for the incorporation of tourism in agriculture. Given the growing tourism industry of the last couple of decades, farmers in Florida should take advantage of this untapped market as a means to complement the returns from their conventional farming operations. By successfully developing a business plan, a management framework and the right marketing strategies, farmers will be able to capitalize on a new farming product (tourism), while improving the environment, conserving wildlife, and maintaining their land heritage. In addition to the sites listed on this publication, more information on alternative enterprises for small farms can be found at http://smallfarms.ifas.ufl.edu.

\section{References}

Anderson, D. H., D. W. Lime, and T. L. Wang. 1998. "Maintaining the Quality of Park Resources and Visitor Experiences: A Handbook For Managers.
TC-777 1998. St. Paul, MN: University of Minnesota, Department of Forest Resources, Cooperative Park Studies Unit and Minnesota Extension Service, Tourism Center. 134 pp. Accessible on-line: http://www.cnr.umn.edu/CPSP/Research/ revtactics_handbook.PDF.

Brady Ranch. Pricing. Available on line at: http://www.bradyranch.com/pricing.htm. Website accessed December, 2006

Clark, R.N. and Stankey, G.H. 1979. The Recreation Opportunity Spectrum: A framework for management, planning, and research. USDA Forest Service. Pacific Northwest Forest and Range Experiment Station. PNW-GTR-93. Corvalis, OR.

Cordell, H.K. 2004. Outdoor Recreation for $21^{\text {st }}$ Century America. A report to the national survey on recreation and the environment. State College Pennsylvania, Venture Publishing.

National Agriculture Statistical Service (NASS). Florida Agricultural Overview - 2006. Available online at http://www.nass.usda.gov/fl/ Website accessed November, 2006

Evans, E.; and Hodges, A. 2006. Potential Impacts of Agritourism in South Miami-Dade County. University of Florida, IFAS Extension Service Publication FE637 Available online at http://edis.ifas.ufl.edu/FE637 Website accessed November, 2006

George, H. and Rilla, E. 2005. Agritourism and Nature Tourism in California. University of California. Oakland, California.

Giuliano, W.M. and Thomas. 2005. Wildlife and Hunting as alternative farm enterprises. University of Florida, IFAS Extension Service Publication WEC197 Available online at http://edis.ifas.ufl.edu/UW224 Website accessed November, 2006

Kolankiewicz and Beck Sprawl in Florida. Sprawl city. Available online at http://www.sprawlcity.org/studyFL/FLsection1.pdf Website access December, 2006 
McKenzie, N. and Wysocki, A. 2002.

Agritainment: A viable option for Florida Producers. University of Florida, IFAS Extension Service Publication rm008 found at http://edis.ifas.ufl.edu/rm008 Website accessed November 2006

Natural Resource Conservation Service (NRCS). Conservation Provisions Overview-2002. Available online at http://www.nrcs.usda.gov/programs/farmbill/2002 Website accessed December, 2006

Stankey, G.H.; Cole, D.N.; Lucas, R.C.; Petersen, M.E.; and Frissell, S.S. 1985. The Limits of Acceptable Change (LAC) System for Wilderness Planning. USDA Forest Service. Intermountain Research Station. INT-GTR-176. Ogden, UT. http://www.fs.fed.us/r8/boone/lac/lac_process.shtml.

Southern Maryland Resources and Conservation Board and USDA Natural Resources Conservation Service. 2004. Taking the First Step: Farm and Ranch Alternative Enterprise and Agritourism Resource Evaluation Guide. Available online at $\mathrm{ftp} / / / \mathrm{ftp}$-fc.sc.egov.usda.gov/Economics/ AltEnterprise/FirstSteps.pdf Website accessed August, 2007.

State of Florida. Florida Quick Facts. Available online at http://www.stateofflorida.com Website accessed November, 2006

Visit Florida. Florida Facts and Themes. Available online at http://media.visitflorida.org/travel/facts/ Website accessed December, 2006. 